
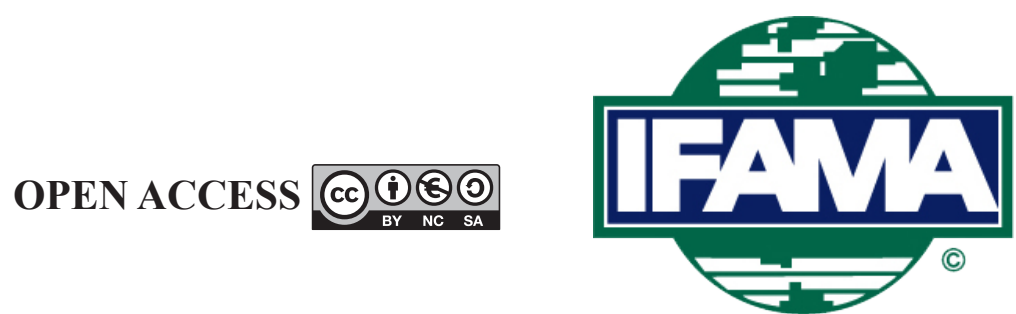

International Food and Agribusiness Management Review

Volume 24, Issue 2, 2021; DOI: 10.22434/IFAMR2020.0094

Received: 16 June 2020 / Accepted: 19 October 2020

\title{
Rural extension and technical efficiency in the Brazilian agricultural sector \\ RESEARCH ARTICLE
}

\author{
Carlos Otavio de Freitas ${ }^{\circledR a}$, Felipe de Figueiredo Silva ${ }^{\mathrm{b}}$, \\ Marcelo Jose Braga ${ }^{\mathrm{c}}$ and Mateus de Carvalho Reis Neves ${ }^{\mathrm{c}}$ \\ aProfessor, Federal Rural University of Rio de Janeiro, Department of Administrative Sciences, \\ BR-465, Kilometer 07, Zona Rural, Seropédica - Rio de Janeiro, 23890-000, Brazil \\ ${ }^{b}$ Assistant Professor, Clemson University, Department of Agricultural Sciences, \\ 235 McAdams Hall, Clemson, SC 29634, USA \\ 'Professor, Federal University of Viçosa, Department of Agricultural Economics, Edson Potsch \\ Magalhães Building - Purdue St, Campus Universitário, Viçosa, 36570-900, Brazil
}

\begin{abstract}
In this paper, we identify the effect of rural extension on the productive performance of Brazilian agricultural establishments, using technical efficiency as a measure of farm performance. The data used is drawn from the microdata of the 2006 Agricultural Census, accessed directly from the IBGE secrecy room. For this, we use an approach that combines the stochastic production frontier, considering selection bias in the adoption of rural extension (Heckman's approach) and entropy balancing. We find that rural extension increases efficiency in the use of the productive inputs, with more technical efficiency found among adopting producers than non-adopters. When considering the differences according to farm size, an even greater effect is observed for larger producers. In addition, public rural extension generates higher technical efficiency scores than those obtained by privately-operated establishments.
\end{abstract}

Keywords: rural extension, entropy balancing, stochastic production frontier, technical efficiency JEL code: Q10, Q12, Q16

\footnotetext{
(1)Corresponding author: carlos.freitas87@gmail.com; carlosfreitas87@ufrrj.br
} 


\section{Introduction}

The agribusiness sector has always been fundamental to economic growth in Brazil, generating income and employment in rural areas (Teixeira et al., 2014). The rapid growth of agriculture and livestock observed in the 1970s, which was driven by the introduction of new technologies, led to the greater dependency of the Brazilian economy on this sector. This performance was the result of several agricultural policies, mainly associated with the provision of resources at low interest rates and the expansion of agricultural research and other instruments (Castro and Pereira, 2017). Delgado (1985) and Nunes et al. (2014) highlight the fundamental role of three agricultural policies in this period: (1) agricultural research initiatives that developed new production technologies; (2) subsidized rural credit, which created opportunities for these technologies to be acquired by producers; and (3) rural extension services, which were responsible for the process of diffusion of new technologies and information to rural producers - this was extremely important for the adoption of these innovations in the production process. Although several papers have evaluated the effects of credit (Castro and Teixeira, 2012; Gasques et al., 2017; Neves et al., 2020) and agricultural research (Barreto and Almeida, 2009; Mendes et al., 2009; Rada and Valdes, 2012) on Brazilian agricultural performance, little has been done to assess the returns of extension services. ${ }^{1}$ In this article, we test whether rural extension plays a significant role in improving farmers' productive performance, as measured by technical efficiency.

Christoplos (2010) argues that one of the purposes of rural extension is to reduce the distance between new research discoveries and farmers during the decision-making process. The diffusion process of new technologies can be accelerated by rural extension, potentially generating significant increases in agricultural productivity and income. In addition to providing information on new technologies, agricultural practices and market price behavior, extension services also include educational activities to develop farmers' management skills, which can also increase production efficiency - even when new technologies are not available.

The National Policy for Technical Assistance and Rural Extension - Pnater, created in 2003 in Brazil - has been responsible for providing most of the extension services ${ }^{2}$ in the country. Rodrigues (1997) claims that public policies affecting rural areas in Brazil had different emphases throughout history. However, he indicates that all these policies focused on the socioeconomic aspects of agricultural establishments, aiming to increase agricultural production and productivity, as well as improving the social well-being of the rural families. ${ }^{3}$

The reformulation of the national rural extension policy, once Pnater was implemented, also led to an increase in the provision of extension services by non-public entities (Pettan, 2010). Since the appearance of technical extension assistance in the 1950s, these services were provided almost exclusively by public or state companies. After the implementation of the new policy, rural extension was also carried out by private companies, integrated companies, cooperatives and other entities. As pointed out by Swinner and Maertens (2007), there is a tendency to increase the provision of extension services by companies that supply inputs or processing companies worldwide.

Despite the advantages offered by rural extension, only $27.7 \%$ of the 4.3 million farms analyzed in this research had access to these programs in 2006 (IBGE, 2019). We also note that accessing these services might be associated with farm size: while the average size of the farms that received the extension service in 2006 was 128.5 ha, the average of those that did not receive it was 44.6 ha. This indicates that most small producers have not received any type of support via rural extension. In addition, access to these services is associated with producers who have higher levels of education. Plata and Fernandes (2012) argue that this may be the result of selection bias in accessing extension services, indicating that larger producers find it easier to access these services because they have higher levels of social mobility, a greater volume of resources and more information for decision-making. These statistics raise the question of whether the extension policy has

\footnotetext{
${ }^{1}$ The next section will present papers that directly or indirectly analyze the effects of the extension on the performance of Brazilian agriculture.

${ }^{2}$ In this research, the Technical Assistance and Rural Extension services (Ater), as defined by Pnater, will only be called 'Rural Extension', in order to standardize the term with the international literature on the topic.

${ }^{3}$ For more details on the emergence and development of extension services in Brazil, see Pettan (2010).
} 
achieved its objective of serving the most technologically backward groups of farmers and small producers, and if, in fact, it has contributed to an increase in the productive performance of Brazilian agriculture.

Accurately evaluating the impacts of rural extension in the agricultural sector is a global challenge (Christoplos et al., 2012). As discussed at the $3^{\text {rd }}$ Global Forum for Rural Advisory Services (GFRAS) in 2012, there is a need for a more detailed evaluation of the role of rural extension, not only in economic performance, but in its capacity to promote sustainable growth in agriculture while also addressing local socioeconomic issues (Christoplos et al., 2012). The allocation of resources to these services would benefit from a rich analysis of their impact to justify the distribution of the investments among different public policies.

An accurate analysis of the returns of rural extension is crucial in Brazil, given the low levels of investment and access in extension services by rural producers, especially those classified as family farms (Peixoto, 2014). There are clear barriers associated with the limited allocation and poor distribution of resources, generating uncertainties about the impact of extension services on the performance of Brazilian farms. Anderson and Feder (2004) contend that this uncertainty contributes to the weakening of political support and aggravates the problems related to budget allocation, the concentration of beneficiaries and the lack of incentives to train professionals, among others. Thus, an accurate assessment of rural extension and its impact can lead to a better understanding of the real importance of this activity, which could justify an increase in investment and government support for this policy, leading to further development of the Brazilian rural sector.

In this paper, our objective is to identify the effect of rural extension on the productive performance of Brazilian farms. Peixoto (2014) and Christoplos et al. (2012) indicate that it is also important to evaluate whether extension services generate improvements in the technical management of a farm, increasing productivity, improving a rural family's well-being and other socioeconomic aspects. In this paper, technical efficiency will be analyzed as a performance measure, which can be interpreted as the way in which an optimal combination of inputs is used in the production process to obtain the maximum output (Lima, 2012). It implies that technical efficiency considers farm management ability, which is associated with the use of scarce resources. A few studies have attempted to indirectly identify the effect of rural extension on technical efficiency in Brazil. Though not the main focus of their research, they generally add a representative variable of the extension service among the determinants of efficiency levels, with different and sometimes

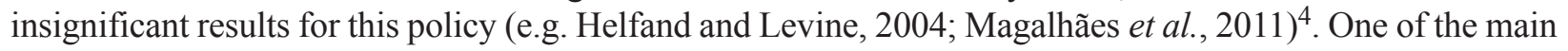
limitations of the literature on rural extension in Brazil is that such research does not take into account the endogenous character of this variable, since the adoption of the extension service is a choice of the farmer, which can be affected by observable factors (such as, for example, experience, characteristics of the farm and others) and unobservable (such as, for example, the farmer's management capacity). By ignoring these characteristics, the results obtained may be biased, which limits any analysis of the importance of rural extension for the performance of Brazilian farms.

We attempt to correct this limitation by combining the stochastic frontier production structure, taking into account selection bias in the adoption of the extension, together with sample matching techniques, in order to identify the effect of rural extension on technical efficiency without including the biases generated by observable and unobservable factors. This strategy also allows us to ascertain which factors influence the probability of the farms to access rural extension services and if there are differences in the allocation of the productive factors between groups. We also test whether the effect of extension programs on efficiency changes according to farm size. To achieve this objective, we use information on 4.3 million farms from the microdata of the 2006 Agricultural Census. This unique and rich dataset allows us to successfully apply the strategy described above, a task that would not be possible using information from the municipal or state level.

Our results indicate that rural extension increases farm technical efficiency and has a greater effect on large farms. We also find that governmental provision of these services has a greater effect on technical farm

\footnotetext{
${ }^{4}$ The results of these and other papers are presented in Section 2.1.
} 
efficiency than non-governmental provision. From a technical efficiency perspective, our findings indicate that farms have benefited from rural extension, as described in the current policy (Pnater). Our results indicate that Plata and Fernandes's (2012) argument is correct: larger farms receive greater returns from rural extension.

\section{Background on rural extension}

\subsection{Rural extension in Brazil}

In Brazil, farms have had access to rural services since the nineteenth century (Bergamasco, 1983). Pettan (2010) argues that rural extension followed the North American model, based on providing educational services and technical assistance, and working in a decentralized way with units in a few Brazilian states. ${ }^{5}$ The first effective attempt to centralize and federalize the extension services originated with the creation of the Brazilian Company of Technical Assistance and Rural Extension (Embrater), which was in charge of rural extension, now exercised by the State Technical Assistance and Rural Extension Companies (Ematers), and partnered with the Brazilian Agricultural Research Corporation (Embrapa), responsible for performing agricultural research, and the National Rural Credit System (SNCR), responsible for providing rural credit to farms.

However, Alex et al. (2002) point out that this system collapsed because of the fiscal crises the country faced in the 1980s, given that rural extension was not a hot topic in governmental agendas until the mid1990s. This scenario changed with the design and implementation of the National Program to Strengthen Family Farming (Pronaf), which featured the importance of rural extension in a few specific types of credit for family farming. Technical assistance provided by companies, input industries and other private sources expanded during this period, when the public offer of rural extension remained stagnant (Peixoto, 2014).

In 2003, the rural extension provision guidelines were defined within the Pnater guidelines, developed by the Ministry of Agrarian Development, which successfully replaced the decentralized government policy introduced in the late 1940s. Peixoto (2014) indicates that this policy sought to build a new rural extension provision structure, incorporating both governmental and non-governmental institutions.

Despite this goal, Alves (2013) suggests that large farms and farms in more developed agricultural regions continued to obtain greater access to rural extension than smaller farms. This contradicts the new policy directions and indicates that more vulnerable groups should receive greater attention. Peixoto (2014) recommends a revision of the provision's structure of these services to incorporate the socioeconomic features described in the Pnater. Rivera and Alex (2004) agree with Christoplos (2010) and maintain that the greater participation of non-governmental institutions within Pnater and a broader rural development agenda would lead to the more efficient provision of these services.

Relatedly, Castro and Pereira (2017) highlight the great disparity among these services provisions. For example, farms in the North and Northeast regions of Brazil have been poorly provided access to this assistance. higher proportion of farms with access is observed in municipalities at the South and Southeast regions of Brazil. On average, $49 \%$ of the farms in the South have had access to these services compared to only $15 \%$ in the North. Although disparities on service provision are still observed, the implementation of Pnater has led to an increase in resources used on rural extension, from R $\$ 3$ million on the 2001/02 crop season to R\$ 1.1 billion on the 2015/16 crop season (Peixoto, 2014). Pettan (2010) and Peixoto (2014) also indicate an increase in non-governmental provisions during this period.

\footnotetext{
${ }_{5}$ According to Pettan (2010), the institutionalization of such services occurred in the 1950s through the creation, at the state level, of the Credit and Rural Assistance Associations (Ascars). This resulted from an agreement between the government of Minas Gerais and the American International Association (AIA), which was responsible for providing the first extension workers as well as the necessary financial support for the operation of Ascars. In the 1970s, the structure of Ascars was absorbed by the state governments, thus creating the State Technical Assistance and Rural Extension Companies (Ematers).
} 
Despite the increase in resources designated for rural extension provision, several Pnater obstacles have led to great disparities in regional provision and farm size access to these services. The Pnater system still has low remuneration for extension agents and large costs to provide rural extension to several farms within each municipality (Peixoto, 2014).

\subsection{Effect of rural extension on technical efficiency}

Several studies have indirectly investigated the effect of rural extension on farm technical efficiency using the stochastic frontier approach. In this approach, the error term is composed by a random standard error and an error term that measures the distance from the frontier or the inefficiency. A few of these studies incorporate heterogeneity in the inefficiency term by including variables that might affect the efficiency level, i.e. a measure of rural extension. However, these studies do not consider the possible effects of selection bias and the endogenous nature of the choice to access rural extension.

As one example, Gonçalves et al. (2008) estimate the technical efficiency of 771 dairy farms in Minas Gerais. They divided the sample into three groups: farms with production below 50 liters of milk per day; those with production between 50 and 200 liters of milk per day; and those with production with more than 200 liters of milk per day. To obtain the technical efficiency scores, they use a Data Envelopment Analysis (DEA) approach and then identify the efficiency determinants using a Tobit regression. The authors include a dummy to capture the effect of rural extension on farm technical efficiency. Their results show a statistically significant effect of rural extension on farm technical efficiency, but only for the farms with the greatest production of milk (more than 200 liters per day). This conclusion adds up to the hypothesis we derived from Alves et al. (2013) and Plata and Fernandes (2012), which states that larger farms benefit more from rural extension.

Using a similar approach, Helfand and Levine (2004) investigate the determinants of the technical efficiency of agricultural farms in the Central West region using the 1995/96 Agricultural Census. Although their variable of interest is farm size, they include access to rural extension as a determinant of farm technical efficiency. They find a positive and significant effect of rural extension on farm technical efficiency. In a related study, Moura et al. (2000) investigate the effect of rural extension services on efficiency and input use of 68 small farms in the state of Ceará. They use a stochastic production function approach where the functional form is based on Cobb-Douglas. The authors find a positive effect of rural extension on farm efficiency. Using a similar approach, Magalhães et al. (2011) investigate the determinants of technical and allocative inefficiency among establishments that participated in the agrarian reform program known as 'Cedula da terra'. This program incorporated establishments in five states of the Northeast region of Brazil. The authors include a dummy variable to capture the effect of rural extension in the efficiency error term and find no effect of this variable on farm technical efficiency.

Finally, Freitas et al. (2019) also identify the effect of rural extension on the agricultural production and technical efficiency of Brazilian agricultural farms, combining the stochastic production frontier with quantile regression methods and using the Agricultural Census of 2006 as a database. They find a positive effect of the rural extension services on technical efficiency only in farms within the lower efficiency quantiles, while for more efficient farms, this variable had a negative effect.

These studies highlight the relevance of rural extension in enabling farm development, productivity and socioeconomic welfare enhancements, and in increasing technical efficiency. However, the literature does not yet include a study that focuses on this topic and uses a suitable methodology that incorporates specific features of this issue, such as the endogenous nature of accessing rural extension. We seek to identify the effect of rural extension on farm technical efficiency and the determinants of the choice to access it using a unique dataset with more than 4 million farm-level observations. 


\section{Methods}

To identify the effect of rural extension on farm technical efficiency, we use an approach that consists of two steps. We first deal with possible selection bias in the choice of accessing rural extension caused by the observable pre-choice characteristics. This possible selection bias does not allow for the direct comparison between the technical efficiency of farms that have access with those that do not. We use the Entropy methodology to eliminate the bias caused by the observable characteristics. This method is used to obtain a control group as similar as possible to the group of farms that have had access to rural extension, which allows us to compare the groups without any possible selection bias. In the second step, we estimate a stochastic production frontier for each group, using the two-stage approach developed by Heckman (1979).

\subsection{Entropy balancing}

We use the 'entropy balancing' method proposed by Hainmueller (2012) to obtain a balanced 'matching' sample. It allows us to find a sample with the closest possible control units of the treatment units based on the vector of observable characteristics. This method consists of a non-parametric method that allows us to weight a set of information (covariates) to reweight the observations in a manner that the distribution of the variables satisfies a set of special conditions at specific moments. The weighting scheme ensures balance and similarity between the control and treatment groups.

Following Hainmueller (2012), consider a random sample with $n_{1}$ observations from the treatment group and $n_{0}$ from the control group, selected from a total population $N=N_{1}+N_{2}$, where $n_{1} \leq N_{1} e n_{0} \leq N_{0}$. Let $D_{\mathrm{i}} \in\{1,0\}$ is a binary treatment variable such as access to rural extension, which assumes a value equal to 1 if unit $i$ is exposed to the treatment, and zero otherwise. Also consider $\mathrm{X}$, a matrix containing observations of the $J$-th exogenous pre-treatment variables; $X_{i j}$ corresponds to the value of the $j$-th covariates of unit $i$, such that $X_{i}=\left[X_{i 1}, X_{i 2}, \ldots, X_{i j}\right]$ refers to the vector of observable characteristics of the unit $i$ e $X_{j}$, which refers to the column vector with $j$-th covariates.

This method looks for a set of weights $W=\left[w_{i}, \ldots, w_{n 0}\right]$ ', minimizing the entropy distance between W and the weight vector $Q=\left[q_{i}, \ldots, q_{n 0}\right]$ ', Equation 1; subject to the balancing constraint, Equation 2; the normalization constraint, Equation 3; and a non-negativity constraint, Equation 4:

$$
\operatorname{Min}_{w_{i}} H(w)=\sum_{\{i \mid D=0\}} w_{i} \log \left(w_{i} / q_{i}\right),
$$

subject to the equilibrium and the normalization constraints

$$
\begin{aligned}
& \sum_{\{i \mid D=0\}} w_{i} c_{r i}\left(X_{i}\right)=m_{r}, r \in 1, \ldots, R \\
& \sum_{\{i \mid D=0\}} w_{i}=1
\end{aligned}
$$

$$
w_{i} \geq 0 \text { for all } i \text {, such that } D=0 \text {, }
$$

Where $q_{i}=1 / n_{0}$ is a basis weight and $c_{r i}\left(X_{i}\right)=m_{r}$ describes a set of $R$ constraints imposed on moments $\left(m_{r}\right)$ of the covariates in the reweighted control group. First, we choose the covariates that will be included in the re-weighting scheme. For each covariate, a set of balancing restrictions (Equation 1) is specified to match the moments of the covariate distribution between treatment groups and reweighted controls. There are three possible moment constraints: mean (first moment), variance (second moment) and asymmetry (third moment). A typical balancing restriction is formulated such that $m_{r}$ contains the moment of a specific covariate $X_{j}$ for the treatment group. The moment function for the control group is then specified as: $c_{r i}\left(X_{i j}\right)$ $=X_{i j}^{r}$ or $c_{r i}\left(X_{i j}\right)=\left(X_{i j}-\mu_{j}\right)^{r}$, where $X_{i j}^{r}$ is the covariate vector and $\mu_{j}$ is the mean. 
We set the moment restriction to the first moment of the covariates. After selecting the covariates, the method calculates the means in the treatment group and searches for a set of entropy weights such that the weighted averages of the control group are similar. Such weights are used in the following steps in order to obtain unbiased estimates of selection bias caused by observable characteristics.

\subsection{Sample selection model}

We use the procedure proposed by Heckman (1979) to test for possible sample selection bias, i.e. factors that affect farm technical efficiency might be different from the factors that determine the likelihood of accessing rural extension services. First, we estimate a binary choice model (selection equation) to find out which factors increase the likelihood of accessing (choosing) rural extension, the treatment variable. Second, we estimate a stochastic production frontier (interest equation) for each group incorporating the inverse Mills ratio, ${ }^{6}$ obtained at the selection equation. We perform this two-step procedure on three different treatment variables: rural extension overall, public rural extension and private rural extension.

\section{- Selection equation}

First, as proposed by Heckman (1979), we estimate the likelihood the treatment will occur using a Probit model, i.e. the likelihood a farm has accessed rural extension. Assume that $d^{*}{ }_{i}$ is a binary variable that represents the (unobservable) selection criterion and that $z_{i}$ is a function of a vector of exogenous variables:

$$
d_{i}^{*}=\alpha^{\prime} z_{i}+w_{i}
$$

where $\alpha$ is a vector of the parameters to be estimated and $w_{i}$ is the error term distributed as $N\left(0, \sigma^{2}{ }_{w}\right)$. The latent variable $d^{*}{ }_{i}$ is observed and receives the value of 1 when $\alpha^{\prime} z_{i}+w_{i}>0$ and zero otherwise:

$$
d_{i}^{*}=1\left[\alpha^{\prime} z_{i}+w_{i}>0\right], w_{i} \sim N[0,1]
$$

\section{- Stochastic production frontier}

Second, we estimate a stochastic production frontier model, correcting for sample bias and the matching sample weighting scheme. This means that we include the inverse Mills ratio and estimate based upon a weight vector obtained using the entropy method. The stochastic frontier approach ${ }^{7}$ has been widely used to obtain efficiency measures. It consists of estimating a production function that represents the relation between agricultural input and output (Helfand et al., 2015; Rada and Valdez, 2012; Theriault and Serra, 2014). Aigner et al. (1977) and Coelli and Battese (1996) specify the model as follows:

$$
Y_{i}=f\left(X_{i}, \beta\right) e^{\left(v_{i}-u_{i}\right)}
$$

Where $Y_{i}$ is the value of production of $i$-th farm; $X_{i}$ is the vector of expenses, with inputs of the $i$-th farm; and $\beta$ is a vector of the parameters to be estimated, which define the production technology. The error terms $v_{i}$ and $u_{i}$ are vectors that represent distinct components of the error: $v_{i}$, the random error component, has a normal distribution, independent and identically distributed (iid), with variance $\sigma_{v}^{2}\left[v \sim i i d N\left(0, \sigma_{v}\right)\right]$ and captures the stochastic effects beyond the control of the productive unit, such as measurement errors and climate, for example; $u_{i}$ is responsible for capturing the technical inefficiency of the $i$-th farm, that is, the distance from the production frontier, and is a non-negative random variable. This unilateral (non-negative) term can follow half-normal, truncated normal, exponential or gamma distributions with mean $\mu>0$ and variance $\sigma^{2}{ }_{u}$

\footnotetext{
${ }^{6}$ Variable generated from the Probit model and included in the stochastic production frontier to correct for sample selection bias. The existence of selection bias is confirmed when the inverse Mills ratio is statistically significant (Heckman, 1979).

${ }^{7}$ According to Aigner et al. (1977) and Chambers (1988), the objective of the model is to estimate a production function in which it is expected to obtain the maximum product from the combination of inputs, considering a certain technological level. However, there is no guarantee that an efficient combination of inputs will be used to maximize production, since there may be technical inefficiencies in the use of these inputs. This implies that the unit may produce less than the maximum production frontier.
} 
(Aigner et al., 1977; Greene, 1980). We have assumed an exponential distribution of the inefficiency error term $\left[u \sim i i d N^{+}\left(0, \sigma_{u}\right)\right]$.

To obtain farm technical efficiency, we follow Jondrow et al. (1982). Farm technical efficiency is defined as the ratio between the observed product and the potential product of the sample:

$$
E T_{i j}=\frac{Y_{i j}}{Y^{*}}=\frac{Y_{i j}}{f\left(X_{i j}\right)}=\frac{\exp \left(X_{i j} \beta+v_{i j}\right) \exp \left(-u_{i j}\right)}{\exp \left(X_{i j} \beta+v_{i j}\right)}=\exp \left(-u_{i j}\right)
$$

where the value of $E T_{i j}$ will be in the range $[0 ; 1]$, where zero represents complete inefficiency and 1 full efficiency.

\subsection{Data and empirical application}

We use a rich farm-level dataset only available in the secrecy room at the IBGE: the microdata of the 2006 Agricultural Census. We first clean the dataset, excluding farms without area declaration $(255,019$ observations); farms located in urban areas (192,350 observations); farms in special sectors such as 'favelas', barracks, indigenous villages, nursing homes, etc. (117,530 observations); and farms in settlements ${ }^{8}(139,496$ observations). We also exclude observations in which the producer type was not identified (20,440 observations) and observations where the farm is not owned by an individual producer (190,838 observations). ${ }^{9}$ Around $17 \%$ of the original data has been dropped as a result, leaving a dataset composed by 4,259,963 farms. In the following section (Table 1), we present a descriptive statistical analysis of our sample.

The three treatment variables - rural extension, public rural extension and private rural extension - are binary variables. They are constructed based on each farmer's answer to the following questions: 'The establishment received technical guidance?' and 'What is the origin of the guidance?' In our sample, $27.7 \%$ of farmers have received technical guidance, $11.4 \%$ from public institutions and $16.3 \%$ from private institution. We also divide our sample in four size classes according to the IBGE classification. We categorize the farms as very small, small, medium and large based on the concept of fiscal module classes. ${ }^{10}$

The Agricultural Census of 2006 also presents farm socioeconomic characteristics. In addition to economic variables, we use these characteristics in the selection equation. We obtain information on farmers' gender, age, educational level and experience. The variable gender is a dummy variable that equals 1 if the farmer is male and zero otherwise. Farmer age is the manager's age. The variable schooling is a categorical variable for the farm manager's education level (from 0 to 7) in the following order: does not read and write, read and write, literate, incomplete elementary school, complete elementary school, agricultural technician, high school and higher education. We capture experience using a categorical variable of the years in which the farmer is in charge of the activity, being divided as follows: up to 1 year, between 1 and 5 years, between 5 and 10 years, over 10 years. Farm ownership, the presence of skilled labor in the farm workforce, family farm classification and whether the farm's manager lives in an urban area also play an important role on the likelihood of accessing rural extension. We capture farm ownership by including a categorical variable: owner (base), tenant, partner and occupant. Skilled labor is captured with a dummy variable that equals 1 if there is skilled labor present on the farm and zero otherwise. Family farm classification is captured in a similar manner. To evaluate whether the farm's manager lives in an urban area or not we construct a dummy variable that equals 1 if the head of the farm lives in an urban area and zero otherwise.

\footnotetext{
${ }^{8}$ Kageyama et al. (2013) suggest that the inclusion of these observations might lead to possible variable measurement error given that agricultural production is performed collectively.

9 We exclude farms categorized as condominium, consortium or partnership, cooperative; corporation or limited liability shares; public utility; government (federal, state, or municipal) or other condition.

${ }^{10}$ Fiscal module is defined as the minimum area required for rural properties to be considered economically viable, ranging in area from 5 to 110 hectares, depending on the municipality. Based on the concept of fiscal module, the agricultural farms can be classified into: very small (less than 1 fiscal module), small (between 1 and 4 fiscal modules), medium (between 4 and 15 fiscal modules) and large (more than 15 fiscal modules) (Landau et al., 2012).
} 
We use the gross value of production in 2006 (GVP) in R $\$$ as a proxy for the output variable $Y_{i}$. We obtain information on four inputs. We use the sum of the farm area (in hectares) designated to agriculture, livestock and agroforestry to capture the land input. The total value in $\mathrm{R} \$$ of the assets in the agricultural establishment is used as a proxy for capital. As a proxy for labor, we use the sum of the family members and hired laborers. As in Helfand et al. (2015), we include a variable to capture purchased inputs (other): the sum of expenses with soil correctives, fertilizers, pesticides, animal medicine, seeds and seedlings, salt/feed, fuel and energy.

\section{- Estimation}

After obtaining the weights for the control groups using the 'entropy balancing' method, we estimate the selection equation using a Probit as in Equation 6:

$$
d_{i}^{*}=\alpha_{0}+\sum_{e=1}^{7} \alpha_{e} Z_{e}+\sum_{0=1}^{3} \alpha_{o} \text { Exp }_{o}+\sum_{k=1}^{7} \alpha_{k} \text { School }_{k}+\sum_{r=1}^{4} \alpha_{r} \text { FarmStatus }_{r}+\varepsilon_{i}
$$

Where $Z_{e}$ is a vector of explanatory variables that includes gender, total farm area (Area), age, age squared, skilled labor (Qualif) in the workforce, family farm classification (Family) and if the farm's manager lives in a urban area (Urban); Exp represents experience and is divided into three categories, School represents schooling and it is divided into seven categories, and farm ownership (FarmStatus) into four categories. We include the square of the variable farm manager's age seeking to capture a nonlinear effect. From this estimation we obtain the inverse Mills ratio (Mills). Then, we include it in the stochastic production frontier.

We use a Translog production function to represent the technology, given that it presents some desirable properties such as flexibility, linearity in parameters, regularity and parsimony (Mariano et al., 2010). In addition to the inverse Mills ratio, we also include in the stochastic production dummy variables for each state and farm size group. In doing so we seek to capture non-observable factors that are fixed across these groups. As in Coelli et al. (2003), the technology can be represented as:

$$
\ln y_{i}=\beta_{0}+\sum_{k=1}^{N} \beta_{k} \ln x_{k i}+\frac{1}{2} \sum_{k=1}^{N} \sum_{h=1}^{N} \ln x_{k i} \ln x_{h i}+\rho M i l l s_{i}+\sum_{h=1}^{26} F S_{h}+\sum_{g=1}^{4} G_{g}+v_{i}-u_{i},
$$

Where $y_{i}$ represents the gross value of production of $i$-th farm; $x_{k i}$ represents inputs $k$, which are: productive area, labor, capital stock and expenses with purchased inputs; $\mathrm{FS}_{\mathrm{h}}$ represents dummies for federative states; and $\mathrm{G}_{\mathrm{g}}$ represents dummies for the four farm sizes considered. We test whether we face selection bias by analyzing the statistical significance of the parameter $\rho$. We have assumed an exponential distribution to the inefficiency error term $\left[u \sim i i d N^{+}\left(0, \sigma_{u}\right)\right]$. We use the STATA ${ }^{\circledR} 2014$ (StataCorp LLC, College Station, TX, USA) software to estimate all steps of this approach.

\section{Results}

We first present the descriptive statistics of the variables used, as displayed in Table 1. This table also shows the result of the entropy method. On average, farms that have had access to rural extension have a greater agricultural area and a manager with higher levels of schooling. They also have shown a greater gross value of production in 2006: on average, $\mathrm{R} \$ 77,300$; as opposed to farms that have not accessed this service, on average, $\mathrm{R} \$ 12,000$. These farms also have a greater input expenditure (fertilizers, agrochemicals, electricity, transportation and others). These disparities is not observed in the averages of age, experience and farm ownership status.

The analysis of Table 1 corroborates the argument in Plata and Fernandes (2012) that medium and large farms have a greater volume of resources and access to information. Farms that have had access to private rural extension have a larger agricultural area, higher schooling and a higher share of the workforce, with skilled labor opposed to farms that have not accessed these services. These farms also obtained, on average, income three times larger in 2006 when compared to the farms that accessed public rural extension. The same behavior is observed in the value of land, buildings and other facilities. 
The columns in the 'balanced sample' of Table 1 show the results of the balancing method using the first moment of the sample (average of the variables). Before using this method, we observe statistically significant differences between the treatment and control groups. However, after using the entropy method, we do not find any statistically significant difference between these groups (test of equality of means). This implies that we are able to obtain very similar controls for each treatment group. The only difference between these two groups is the access to rural extension services.

\subsection{Sample selection}

We present in Table 2 the determinants of the likelihood to access rural extension services using a Probit model. We reject the null hypothesis of joint insignificance of the variables $\left(x^{2}\right)$ at $1 \%$ in all models considered. We find that larger farms face greater likelihood of accessing rural extension services. This confirms the hypothesis that larger farms have higher access to rural extension. Being male is associated with a greater probability of accessing these services, compared to being female. We also find that farms with managers that have more experience have a higher probability to access these services.

Table 1. Mean of the variables used in the selection equation and the stochastic production frontier. ${ }^{1}$

\begin{tabular}{|c|c|c|c|c|c|c|c|c|c|c|}
\hline \multirow[b]{2}{*}{ Variables } & \multicolumn{4}{|c|}{ Non-balanced sample } & \multicolumn{6}{|c|}{ Balanced sample } \\
\hline & $\begin{array}{l}\text { Without RE } \\
\text { (control) }\end{array}$ & $\mathbf{R E}$ & Public RE & Private RE & $\begin{array}{l}\text { Without RE } \\
\text { (control) }\end{array}$ & $\mathbf{R E}$ & Control & Public RE & Control & Private $\mathbf{R E}$ \\
\hline Gender & 0.863 & $0.933 * * *$ & $0.921 * * *$ & $0.940 * * *$ & 0.933 & $0.933^{\mathrm{ns}}$ & 0.921 & $0.922^{\mathrm{ns}}$ & 0.940 & $0.940^{\mathrm{ns}}$ \\
\hline Total area & 44.56 & $128.5 * * *$ & $66.00 * * *$ & $172.5^{* * *}$ & 128.5 & $128.500^{\mathrm{ns}}$ & 65.99 & $66.000^{\mathrm{ns}}$ & 172.4 & $172.500^{\mathrm{ns}}$ \\
\hline Age & 50.5 & $49.56 * * *$ & $50.61 * * *$ & $48.82 * * *$ & 49.56 & $49.560^{\mathrm{ns}}$ & 50.61 & $50.610^{\text {ns }}$ & 48.82 & $48.820^{\text {ns }}$ \\
\hline Read and write & 0.108 & $0.0462 * * *$ & $0.0666^{* * *}$ & $0.0319 * * *$ & - & - & - & - & - & - \\
\hline Do not read and write & 0.295 & $0.0685^{* * *}$ & $0.116^{* * *}$ & $0.0352 * * *$ & 0.069 & $0.068^{\text {ns }}$ & 0.116 & $0.116^{\mathrm{ns}}$ & 0.036 & $0.035^{\mathrm{ns}}$ \\
\hline Literate & 0.0577 & $0.0341 * * *$ & $0.0467 * * *$ & $0.0252 * * *$ & 0.034 & $0.034^{\mathrm{ns}}$ & 0.047 & $0.047^{\mathrm{ns}}$ & 0.025 & $0.025^{\mathrm{ns}}$ \\
\hline Incomplete elementary & 0.404 & $0.506 * * *$ & $0.526 * * *$ & $0.491 * * *$ & 0.506 & $0.506^{\mathrm{ns}}$ & 0.526 & $0.526^{\mathrm{ns}}$ & 0.491 & $0.491^{\mathrm{ns}}$ \\
\hline Complete elementary & 0.072 & $0.121 * * *$ & $0.113 * * *$ & $0.127 * * *$ & 0.121 & $0.121^{\mathrm{ns}}$ & 0.113 & $0.113^{\text {ns }}$ & 0.127 & $0.127^{\mathrm{ns}}$ \\
\hline Agricultural technician & 0 & $0.0607^{\mathrm{ns}}$ & $0.0178 * * *$ & $0.0909 * * *$ & 0 & 0 & 0.018 & $0.018^{\text {ns }}$ & 0.091 & $0.091^{\mathrm{ns}}$ \\
\hline High school & 0.0482 & $0.0966^{* * *} *$ & $0.0803 * * *$ & $0.108 * * *$ & 0.097 & $0.097^{\mathrm{ns}}$ & 0.080 & $0.080^{\mathrm{ns}}$ & 0.108 & $0.108^{\mathrm{ns}}$ \\
\hline Higher education & 0.0155 & $0.0669 * * *$ & $0.0339 * * *$ & $0.0900 * * *$ & 0.067 & $0.067^{\mathrm{ns}}$ & 0.034 & $0.034^{\mathrm{ns}}$ & 0.090 & $0.090^{\mathrm{ns}}$ \\
\hline $\exp 1$ & 0.0281 & $0.0190 * * *$ & $0.0168 * * *$ & $0.0205 * * *$ & 0.019 & $0.019^{\text {ns }}$ & 0.017 & $0.017^{\mathrm{ns}}$ & 0.021 & $0.021^{\mathrm{ns}}$ \\
\hline $\exp 2$ & 0.169 & $0.152 * * *$ & $0.140 * * *$ & $0.161 * * *$ & 0.153 & $0.153^{\mathrm{ns}}$ & 0.140 & $0.140^{\mathrm{ns}}$ & 0.161 & $0.161^{\mathrm{ns}}$ \\
\hline exp3 & 0.168 & $0.173 * * *$ & $0.172 * * *$ & $0.174 * * *$ & 0.173 & $0.173^{\text {ns }}$ & 0.172 & $0.172^{\text {ns }}$ & 0.174 & $0.174^{\mathrm{ns}}$ \\
\hline exp4 & 0.635 & $0.656 * * *$ & $0.671 * * *$ & $0.645 * * *$ & - & - & - & - & - & - \\
\hline Qualif & 0.0236 & $0.0964 * * *$ & $0.0621 * * *$ & $0.121 * * *$ & 0.096 & $0.096^{\mathrm{ns}}$ & 0.062 & $0.062^{\mathrm{ns}}$ & 0.121 & $0.121^{\mathrm{ns}}$ \\
\hline Family & 0.876 & $0.745 * * *$ & $0.821 * * *$ & $0.692 * * *$ & 0.745 & $0.745^{\mathrm{ns}}$ & 0.821 & $0.821^{\mathrm{ns}}$ & 0.692 & $0.692^{\mathrm{ns}}$ \\
\hline Urban & 0.118 & $0.194 * * *$ & $0.136^{* * *}$ & $0.234 * * *$ & 0.194 & $0.194^{\mathrm{ns}}$ & 0.136 & $0.136^{\mathrm{ns}}$ & 0.234 & $0.235^{\mathrm{ns}}$ \\
\hline Owner & 0.824 & $0.894 * * *$ & $0.905 * * *$ & $0.887 * * *$ & 0.894 & $0.894^{\mathrm{ns}}$ & 0.905 & $0.905^{\mathrm{ns}}$ & 0.887 & $0.887^{\mathrm{ns}}$ \\
\hline Tenant & 0.0451 & $0.0530 * * *$ & $0.0354 * * *$ & $0.0653 * * *$ & 0.053 & $0.053^{\mathrm{ns}}$ & 0.035 & $0.035^{\text {ns }}$ & 0.065 & $0.065^{\mathrm{ns}}$ \\
\hline Partner & 0.0316 & $0.0172 * * *$ & $0.0173 * * *$ & $0.0170 * * *$ & 0.017 & $0.017^{\mathrm{ns}}$ & 0.017 & $0.017^{\mathrm{ns}}$ & 0.017 & $0.017^{\mathrm{ns}}$ \\
\hline Occupant & 0.0997 & $0.0355 * * *$ & $0.0424 * * *$ & $0.0307 * * *$ & - & - & - & - & - & - \\
\hline GVP & 12,009 & 77,292 & 35,761 & 106,488 & - & - & - & - & - & - \\
\hline Labor & 2.559 & 3.272 & 2.953 & 3.497 & - & - & - & - & - & - \\
\hline Area & 28.53 & 91.81 & 45.71 & 124.2 & - & - & - & - & - & - \\
\hline Capital & 101,960 & 524,921 & 236,827 & 727,447 & - & - & - & - & - & - \\
\hline Purchased inputs & 1,995 & 31,938 & 9,117 & 47,981 & - & - & - & - & - & - \\
\hline No. Obs. & $3,336,328$ & 923,228 & 381,104 & 542,124 & $3,336,328$ & 923,228 & & 381,104 & & 542,124 \\
\hline
\end{tabular}

${ }^{1} \mathrm{RE}=$ rural extension; *** means are statistically different from the control group (no extension) at $1 \%$; NS = means are statistically the same as the control group at $1 \%$. 
Table 2. Estimation of the selection equation (Probit) for participation in rural extension services, after balancing the sample. ${ }^{1}$

\begin{tabular}{|c|c|c|c|}
\hline Variables & Rural extension (1) & Public rural extension (2) & Private rural extension (3) \\
\hline Gender & $0.393 * * *(0.00258)$ & $0.237 * * *(0.00302)$ & $0.389 * * *(0.00322)$ \\
\hline Total Area & $7.68 \mathrm{e}-05 * * *(1.64 \mathrm{e}-06)$ & $-3.96 \mathrm{e}-05^{* * *}(2.53 \mathrm{e}-06)$ & $9.24 \mathrm{e}-05 * * *(1.59 \mathrm{e}-06)$ \\
\hline Age & $0.0340 * * *(0.000324)$ & $0.0268 * * *(0.000388)$ & $0.0257 * * *(0.000384)$ \\
\hline Age2 & $-0.000302 * * *(3.08 \mathrm{e}-06)$ & $-0.000229 * * *(3.67 \mathrm{e}-06)$ & $-0.000239 * * *(3.68 \mathrm{e}-06)$ \\
\hline Read and write & $-1.115 * * *(0.00497)$ & $-0.327 * * *(0.00621)$ & $-1.231 * * *(0.00557)$ \\
\hline Do not read and write & $-1.386 * * *(0.00468)$ & $-0.507 * * *(0.00587)$ & $-1.574 * * *(0.00527)$ \\
\hline Literate & $-0.946 * * *(0.00535)$ & $-0.206 * * *(0.00663)$ & $-1.063 * * *(0.00604)$ \\
\hline Incomplete Elementary & $-0.515 * * *(0.00426)$ & $-0.00855(0.00546)$ & $-0.570 * * *(0.00438)$ \\
\hline Complete Elementary & $-0.334 * * *(0.00463)$ & $0.0842 * * *(0.00589)$ & $-0.401 * * *(0.00480)$ \\
\hline Agricultural Technician & - & $0.0700 * * *(0.00853)$ & $1.579 * * *(0.00799)$ \\
\hline High School & $-0.259 * * *(0.00473)$ & $0.108 * * *(0.00603)$ & $-0.325 * * *(0.00489)$ \\
\hline Exp1 & $-0.344 * * *(0.00513)$ & $-0.213 * * *(0.00636)$ & $-0.305 * * *(0.00593)$ \\
\hline Exp2 & $-0.162 * * *(0.00223)$ & $-0.0808 * * *(0.00268)$ & $-0.157 * * *(0.00258)$ \\
\hline Exp3 & $-0.0919 * * *(0.00209)$ & $-0.0128 * * *(0.00248)$ & $-0.121 * * *(0.00244)$ \\
\hline Qualif. & $0.484 * * *(0.00346)$ & $0.157 * * *(0.00410)$ & $0.445 * * *(0.00357)$ \\
\hline Family & $-0.274 * * *(0.00201)$ & $-0.0323 * * *(0.00251)$ & $-0.336 * * *(0.00221)$ \\
\hline Urban & $-0.0575 * * *(0.00224)$ & $-0.138 * * *(0.00275)$ & $0.0264 * * *(0.00247)$ \\
\hline Tenant & $0.137 * * *(0.00348)$ & $-0.135 * * *(0.00455)$ & $0.282 * * *(0.00383)$ \\
\hline Partner & $-0.178 * * *(0.00500)$ & $-0.194 * * *(0.00614)$ & $-0.0998 * * *(0.00598)$ \\
\hline Occupant & $-0.418 * * *(0.00330)$ & $-0.298 * * *(0.00389)$ & $-0.391 * * *(0.00417)$ \\
\hline Constant & $-1.086^{* * *}(0.00972)$ & $-2.069 * * *(0.0119)$ & $-1.159 * * *(0.0112)$ \\
\hline Log likelihood & $-1.894 \mathrm{e}+06$ & $-1.238 \mathrm{e}+06$ & $-1.330 \mathrm{e}+06$ \\
\hline chi2 & $492,307 * * *$ & $90,057 * * *$ & $587,009 * * *$ \\
\hline
\end{tabular}

$1 * * *$ significant at $1 \%$; standard errors in parentheses.

Our results suggest that farms with managers with a high level of education have a greater probability of accessing rural extension services. Similarly, Lapple and Hennessy (2014) investigate the participation of dairy farms in extension programs in the United States, and they also find that higher education levels increase the adoption of these services. The authors highlight the importance of investments in rural education to facilitate access to rural extension for the following reasons: the farmer's inherent motivation to obtain information and knowledge and/or the extension services, which are often promoted by agricultural education. Farms classified as 'family agriculture' and farm managers who live in urban areas lead to a lower probability of accessing rural extension services. Genius et al. (2006) also find similar results. We further find that hiring skilled labor increases the probability of accessing these services.

For the treatment variables, private rural extension and public rural extension, also in Table 2, we do not observe any difference on the effects of gender, age, skilled labor and experience. However, we observe that the higher education of the farm's manager has a stronger effect on the probability of accessing private extension compared to public services. Where a farm's manager lives also has a different impact: positive on the probability to access private rural extension and negative on accessing public services. Swinnen and Maertens (2007) indicate that part of the private extension services is carried out by input suppliers and/or food processing and distribution companies. A higher level of interaction between farm managers and these companies is expected when farm managers live in urban areas. 


\subsection{Stochastic production frontier}

We estimate the stochastic production frontier function for the entire sample and for each group of the rural extension services. In addition to the inputs, the inverse Mills ratio, estimated in the previous step, is included in the production function to correct for possible selection bias caused by unobservable factors. We estimate the Translog production function using the weighting scheme from the entropy method. The Wald statistic indicates that the model has a good fit, rejecting at $1 \%$ the null hypothesis of joint insignificance of the variables. Results are shown in Table 3.

Our results suggest that unobservable factors influence a producer's decision to access rural extension services. We confirm the hypothesis of sampling selection bias, demonstrated in the statistical significance of the coefficients for the IMR. The negative coefficient found in all three models suggests that these factors are associated with the selection of producers at the lower level of gross value of production. Our results also suggest that most of the error is due to inefficiency, given that the value of the Lambda parameter found is above the unit in all the estimated models.

We estimate the production elasticities for land, labor, capital and purchased inputs, as displayed in Table 4. The sum of these elasticities gives us a measure of returns to scale. We find it to be close to one in all models, which suggests that the technology used is under constant returns to scale. Alves et al. (2012) find a similar result using the same data. For the pooled model, we find that other and labor were the inputs with the greatest production elasticities. An increase of $10 \%$ in these inputs would lead to an increase, on average, of 4.4 and $3.2 \%$ in production, respectively. Helfand et al. (2015) also find that these inputs have the greatest elasticities for Brazilian agriculture. ${ }^{11}$

We find significant differences in the production elasticities in the models of the treatment and control groups. For both groups, purchased inputs still has the greatest production elasticity. For the treatment group, there is a greater contribution of capital and labor compared to the control group, as expected. One of the main goals of rural extension is to facilitate the access to new technologies and knowledge, which leads to greater investment and capital use, generating higher agricultural income. Land production elasticity is greater for the control group. This group is composed mostly by small farmers who often increase production by expanding the productive area. This occurs because of a lack of knowledge regarding more productive techniques or constrained access to financial resources.

The production elasticities of purchased inputs and labor were the greatest in the two models related to the type of rural extension: public and private. The capital production elasticity is around 6 percentage points higher for farmers who have accessed private rural extension compared to farmers who have accessed public services. Farms that have access to private rural extension usually have greater financial resources available. This allows them to have greater investment in capital goods, which also facilitates the actions of extension agents.

\subsection{Analysis of technical efficiency scores}

We obtain unbiased farm technical efficiency scores for the five models estimated, and we present the mean and the standard deviation in Table $5 .{ }^{12}$ We observe that the average technical efficiency of the farms that had access to rural extension was $32.1 \%$, opposed to $31.4 \%$ from the farms that did not have access. This suggests that farms that had access to these services are technically more efficient than the others. The value of the estimated standard deviation for both groups ( 0.22 and 0.19 , respectively) shows the dispersion of the data, which reflects the high level of heterogeneity in the sample.

\footnotetext{
${ }^{11}$ The elasticities found by Helfand et al. (2015) for purchased inputs and labor are, respectively, 0.62 and 0.21 . Although the authors also use the 2006 Agricultural Census, they use a more aggregated database, with information grouped in representative farms.

12 It should be emphasized that, among the rules for the use of the secrecy room in the IBGE, it is not allowed to extract any maximum and minimum values in order to prevent any producer from being identified through such information.
} 
Table 3. Estimation of stochastic production frontier for the total sample and for the different treatment groups considered.

\begin{tabular}{|c|c|c|c|c|c|}
\hline Ly(GVP) & $\begin{array}{l}\text { Total sample } \\
\text { (pooled) (1) }\end{array}$ & $\begin{array}{l}\text { Rural extension } \\
(2)\end{array}$ & $\begin{array}{l}\text { Without rural } \\
\text { extension (3) }\end{array}$ & $\begin{array}{l}\text { Public rural } \\
\text { extension (4) }\end{array}$ & $\begin{array}{l}\text { Private rural } \\
\text { extension (5) }\end{array}$ \\
\hline \multirow[t]{2}{*}{ 1x1 (area) } & $0.454 * * *$ & $0.437 * * *$ & $0.423 * * *$ & $0.332 * * *$ & $0.486^{* * *}$ \\
\hline & $(0.0029)$ & $(0.0076)$ & $(0.0033)$ & $(0.0108)$ & $(0.0103)$ \\
\hline \multirow[t]{2}{*}{ 1x2 (labor) } & $0.204 * * *$ & $0.294 * * *$ & $0.193 * * *$ & $0.223 * * *$ & $0.516 * * *$ \\
\hline & $(0.0078)$ & $(0.0175)$ & $(0.0095)$ & $(0.0268)$ & $(0.0238)$ \\
\hline \multirow[t]{2}{*}{ 1x3 (purchased inputs) } & $-0.116 * * *$ & $0.0859 * * *$ & $-0.0953 * * *$ & $-0.0547 * * *$ & $0.161 * * *$ \\
\hline & $(0.0019)$ & $(0.0056)$ & $(0.0024)$ & $(0.0082)$ & $(0.0077)$ \\
\hline \multirow[t]{2}{*}{ 1x4 (capital) } & $-0.288 * * *$ & $-0.233 * * *$ & $-0.262 * * *$ & $-0.221 * * *$ & $-0.233 * * *$ \\
\hline & $(0.0029)$ & $(0.0069)$ & $(0.0036)$ & $(0.0095)$ & $(0.0098)$ \\
\hline \multirow[t]{2}{*}{ lx 12} & $-0.0031 * * *$ & $0.0491 * * *$ & $-0.0006^{\mathrm{NS}}$ & 0.00112 & $0.0768 * * *$ \\
\hline & $(0.0005)$ & $(0.0013)$ & $(0.0006)$ & $(0.0020)$ & $(0.0017)$ \\
\hline \multirow[t]{2}{*}{$1 \times 22$} & $-0.0065 * *$ & $0.103 * * *$ & $0.0008 \mathrm{NS}$ & $0.0719 * * *$ & $0.149 * * *$ \\
\hline & $(0.0032)$ & $(0.0048)$ & $(0.0038)$ & $(0.0091)$ & $(0.0056)$ \\
\hline \multirow[t]{2}{*}{$1 \times 32$} & $0.0978 * * *$ & $0.0973 * * *$ & $0.102 * * *$ & $0.103 * * *$ & $0.0916^{* * *}$ \\
\hline & $(0.0003)$ & $(0.0005)$ & $(0.0003)$ & $(0.0008)$ & $(0.0007)$ \\
\hline \multirow[t]{2}{*}{$1 \times 42$} & $0.0349 * * *$ & $0.0508 * * *$ & $0.0317 * * *$ & $0.0363 * * *$ & $0.0576 * * *$ \\
\hline & $(0.0004)$ & $(0.0008)$ & $(0.0004)$ & $(0.0012)$ & $(0.0011)$ \\
\hline \multirow[t]{2}{*}{$1 \times 1 \times 2$} & $-0.0243 * * *$ & $-0.0281 * * *$ & $-0.0234 * * *$ & $-0.0105^{* * *}$ & $-0.0343 * * *$ \\
\hline & $(0.0010)$ & $(0.0019)$ & $(0.0011)$ & $(0.0032)$ & $(0.0023)$ \\
\hline \multirow[t]{2}{*}{$1 \times 1 \times 3$} & $-0.0174 * * *$ & $-0.0275^{* * *}$ & $-0.0209 * * *$ & $-0.0195 * * *$ & $-0.0284 * * *$ \\
\hline & $(0.0003)$ & $(0.0007)$ & $(0.0003)$ & $(0.0010)$ & $(0.0009)$ \\
\hline \multirow[t]{2}{*}{$1 \times 1 \times 4$} & $-0.0097 * * *$ & $-0.0196 * * *$ & $-0.0046 * * *$ & $-0.0043 * * *$ & $-0.0296 * * *$ \\
\hline & $(0.0003)$ & $(0.0008)$ & $(0.0004)$ & $(0.0011)$ & $(0.0010)$ \\
\hline \multirow[t]{2}{*}{$1 \times 2 \times 3$} & $-0.0608 * * *$ & $-0.0492 * * *$ & $-0.0694 * * *$ & $-0.0504 * * *$ & $-0.0619 * * *$ \\
\hline & $(0.0006)$ & $(0.0015)$ & $(0.0007)$ & $(0.0022)$ & (0.0019) \\
\hline \multirow[t]{2}{*}{$1 \times 2 \times 4$} & $0.0514 * * *$ & $0.0303 * * *$ & $0.0567 * * *$ & $0.0321 * * *$ & $0.0224 * * *$ \\
\hline & $(0.0009)$ & $(0.0020)$ & $(0.0011)$ & $(0.0030)$ & $(0.0025)$ \\
\hline \multirow[t]{2}{*}{$1 \times 3 \times 4$} & $0.0031 * * *$ & $-0.0209 * * *$ & $-0.00125 * * *$ & $-0.0092 * * *$ & $-0.0251 * * *$ \\
\hline & $(0.0002)$ & $(0.0007)$ & $(0.0003)$ & $(0.00095)$ & $(0.0008)$ \\
\hline \multirow[t]{2}{*}{ Mills } & - & $-0.0151 * * *$ & $-0.0446 * * *$ & - & - \\
\hline & & $(0.0020)$ & $(0.0011)$ & & \\
\hline \multirow[t]{2}{*}{ Millspub } & - & - & - & $-0.0119 * * *$ & - \\
\hline & & & & $(0.0046)$ & \\
\hline \multirow[t]{2}{*}{ Millspriv } & - & - & - & - & $-0.0120 * * *$ \\
\hline & & & & & $(0.0033)$ \\
\hline \multirow[t]{2}{*}{ Constant } & $7.897 * * *$ & $7.314 * * *$ & $8.039 * * *$ & $7.790 * * *$ & $6.945 * * *$ \\
\hline & $(0.0186)$ & $(0.0434)$ & $(0.0214)$ & $(0.0632)$ & $(0.0637)$ \\
\hline \multirow[t]{2}{*}{ Usigma } & $1.571 * * *$ & $1.101 * * *$ & $1.822 * * *$ & $1.165 * * *$ & $1.194 * * *$ \\
\hline & $(0.00128)$ & $(0.00278)$ & $(0.0014)$ & $(0.0043)$ & $(0.0034)$ \\
\hline \multirow[t]{2}{*}{ Vsigma } & $0.0814 * * *$ & $-0.385 * * *$ & $0.0458 * * *$ & $-0.224 * * *$ & $-0.497 * * *$ \\
\hline & $(0.00134)$ & $(0.00274)$ & $(0.0016)$ & $(0.0042)$ & $(0.0036)$ \\
\hline Lambda & 19.299 & 2.859 & 39.782 & 5.201 & 2.402 \\
\hline Wald-test & $3.016 \mathrm{e}+06$ & 738,658 & $1.783 \mathrm{e}+06$ & 229,269 & 476,631 \\
\hline Prob $>$ chi 2 & 0.000 & 0.000 & 0.000 & 0.000 & 0.000 \\
\hline Observations & $4,259,963$ & 867,145 & $3,336,328$ & 381,104 & 542,124 \\
\hline
\end{tabular}

$1 * * *, * *, *$, significant at $1,5,10 \%$, respectively; standard errors (bootstrap) in parentheses. 
Table 4. Elasticities of the inputs for the total sample and for the different treatment groups considered.

\begin{tabular}{lccccc}
\hline & Area & Labor & Purchased inputs & Capital & Sum \\
\hline \multirow{2}{*}{ Total sample (pooled) } & 0.2316 & 0.3183 & 0.4372 & 0.1023 & 1.0894 \\
& $(0.0018)$ & $(0.0035)$ & $(0.0013)$ & $(0.0016)$ & \\
Rural extension & 0.1469 & 0.3421 & 0.3700 & 0.1436 & 1.0025 \\
& $(0.0036)$ & $(0.0066)$ & $(0.0024)$ & $(0.0030)$ & \\
Without rural extension & 0.2367 & 0.3171 & 0.4313 & 0.0843 & 1.0694 \\
& $(0.0017)$ & $(0.0038)$ & $(0.0013)$ & $(0.0015)$ & \\
Public rural extension & 0.1696 & 0.2900 & 0.3994 & 0.1071 & 0.9662 \\
& $(0.0053)$ & $(0.0105)$ & $(0.0038)$ & $(0.0044)$ & \\
Private rural extension & 0.1353 & 0.4369 & 0.3675 & 0.1634 & 1.1030 \\
& $(0.0047)$ & $(0.0086)$ & $(0.0031)$ & $(0.0040)$ & \\
\hline
\end{tabular}

${ }^{1}$ All elasticities were statistically significant at $1 \%$. Standard errors in parentheses.

The use of a heterogenous and large sample leads to low average technical efficiency. Alves et al. (2012) also use microdata from the 2006 Agricultural Census and find that around $66 \%$ of the farms produce around $3 \%$ of the gross value of production. They also argue that around $64 \%$ of these farms were not able to pay for their inputs. It is very likely that these farms were located in the lower part of the technical efficiency distribution, which pulls down the average efficiency.

Studies using more aggregate data usually find higher average technical efficiency because these farms are geographically dispersed. Magalhães et al. (2011) use a more homogenous sample and find an average technical efficiency of 47\%. Almeida (2012) employs a more aggregate sample and finds an average technical efficiency of 92\%. On the other hand, Schuntzemberger and Sampaio (2018) also analyzed efficiency of Brazilian farms using the microdata from the 2006 Agricultural Census and find an average technical efficiency of $32 \%$. Although we find low averages, we are interested in the difference between groups. We believe that the magnitude of these differences is not affected by the level of efficiency.

We find that farms that have accessed public rural extension have a technical efficiency average 2 percentage points higher than the technical efficiency average of farms that have accessed private rural extension. This result can be explained by the fact that farms that have accessed public rural extension are associated with relatively low use of inputs (land, labor, capital and purchased inputs). Then the role of extension agents is to transfer knowledge, teach alternative agricultural practices and assist farmers in managing scarce resources more efficiently. Peixoto (2014) states that the acquisition of large input quantities and the adoption of more advanced technologies is limited because of budget and credit constraints. Private rural extension mainly provided by input suppliers and private technical assistance companies is associated with the purchase of technological packages (including seeds, machinery and other agricultural technologies). Even though this potentially raises productivity, these packages and the combo extension do not necessarily imply greater technical efficiency in the use of productive inputs compared to farms with public extension.

Table 5. Mean and standard deviation of the technical efficiency scores for rural extension group.

\begin{tabular}{lrrl}
\hline & No. obs. & Mean & Standard deviation \\
\hline Balanced sample & & & \\
Rural extension & 923,228 & 0.3209 & 0.2245 \\
Without rural extension & $3,336,328$ & 0.3137 & 0.1998 \\
Type of extension & & & \\
Public rural extension & 381,104 & 0.3285 & 0.2178 \\
Private rural extension & 542,124 & 0.3077 & 0.2274 \\
\hline
\end{tabular}


In Figure 1 we display the technical efficiency averages per farm size and group considered in this paper. 'Small' farms have shown the highest technical efficiency averages. As the farm size increases, the average score decreases. Our results corroborate what has been found in the literature: a U-inverted relationship between farm size and technical efficiency exists in which small farms have the highest efficiency scores (Freitas et al., 2019; Helfand et al., 2015).

These results also demonstrate the heterogeneity that exists within family farming in Brazil. Our results for technical efficiency of 'small' farms might be an indication that the government's strategy in defining specific policies for family farming is working, leading to increases in the productive performance of such farmers. However, we have a group of 'very small' farms that are technically inefficient and are probably fighting rural poverty. Even though farms in this group are eligible for agricultural policies associated with family farming, such as public rural extension, the data identifies them as the group benefitting the least: only $16 \%$ of the 3 million farms in this group have accessed rural extension. In comparing the average technical efficiencies between groups with access to rural extension and those without access, the results show that the gains in technical efficiency due to access to extension increases with farm size. For example, the difference in technical efficiency due the access to this service is approximately 4 percentage points between medium and large farms.

\section{Conclusions}

In this paper we sought to estimate the unbiased effect of rural extension on the technical efficiency of farms in Brazil using a stochastic frontier approach that considers sample selection bias and the endogeneity of the treatment variable. We have found that a more educated farm manager, more skilled labor in the workforce and the farm ownership status are factors that increase the likelihood of accessing rural extension services. The production elasticity results indicated that farms that have not accessed rural extension services rely more on land input as opposed to farms that have accessed these services. We also find that the private access to these services increases the capital production elasticity, which indicates that these services are capitalintensive. Our estimates of technical efficiency suggest that public provision of these services increases farm technical efficiency, compared to non-access or private access. We find a greater effect among large farmers, an increase of 4 percentage points compared to the effect of extension in the other farm sizes groups.

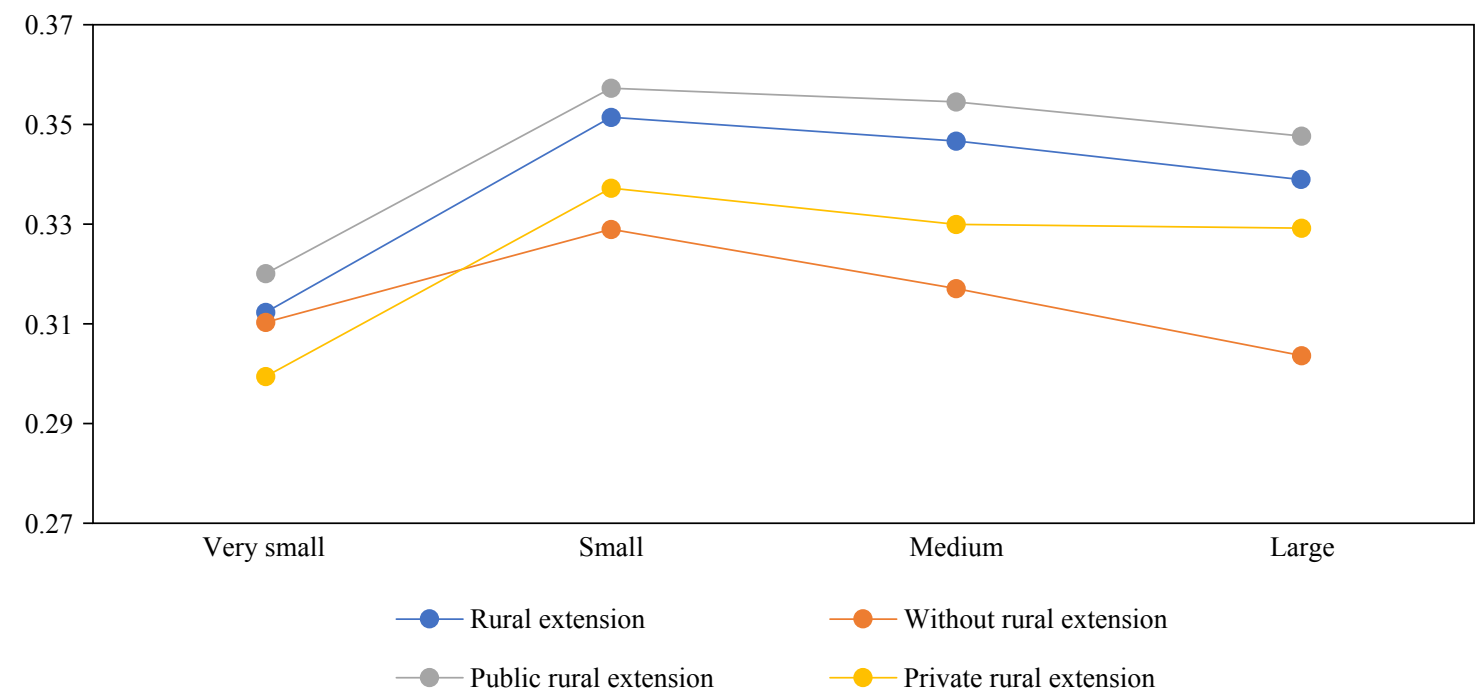

Figure 1. Averages of the technical efficiency scores by farm size. 
Our findings suggest that an increase in public investment for rural extension would result in greater development of rural areas given its effect on agricultural technical efficiency. Although small farms are the main focus of these services, large farms benefit more from them. In other words, a more organized strategy such as greater access to rural credit is needed to obtain a more effective rural extension effect among small producers. This will increase the likelihood of accessing these services and the availability of new technology and knowledge, which is already being used by large farms.

\section{Acknowledgements}

The authors would like to thank the Brazilian Institute of Geography and Statistics for allowing access to the Agricultural Census of 2006 dataset.

\section{References}

Aigner, D.J., C.A.K. Lovell and P. Schmidt. 1977. Formulation and estimation of stochastic frontier production function models. Journal of Econometrics 6(1): 21-37.

Alex, G., W. Zijp and D. Byerlee. 2002. Rural extension and advisory services: new directions. Rural development strategy background. Agriculture and Rural Department, The World Bank, Washington, DC, USA.

Almeida, P.N. 2012. Fronteira de produção e eficiência técnica da agropecuária Brasileira em 2006. PhDthesis, Escola Superior de Agricultura 'Luiz de Queiroz', São Paulo, Brazil.

Alves, E. 2013. Excluídos da modernização da agricultura. Responsabilidade da Extensão Rural? Revista de Política Agrícola 3: 3-5.

Alves, E., G.S. Souza and D.P. Rocha. 2012. Lucratividade da Agricultura. Revista de Política Agrícola 21(2): 45-63.

Alves, E., G.S. Souza and D.P. Rocha. 2013. Desigualdade nos campos na ótica do Censo Agropecuário 2006. Revista de Política Agrícola 22(2): 67-75.

Anderson, J.R and G. Feder. 2004. Agricultural extension: good intentions and hard realities. The World Bank Research Observer 19(1): 41-60.

Barreto, R.C.S. and E. Almeida. 2009. A contribuição da pesquisa para convergência e crescimento da renda agropecuária no Brasil. Revista de Economia e Sociologia Rural 47(3): 719-737.

Bergamasco, S.M.P.P. 1983. Agricultura e Assistência Técnica no Estado de São Paulo. PhD-thesis, Universidade Estadual de São Paulo, Botacatu, SP, Brazil.

Castro, C.N.D. and C.N. Pereira. 2017. Agricultura familiar, assistência técnica e extensão rural e a política nacional de ATER. Texto para discussão No. 2343. Instituto de Pesquisa e Economia Aplicada, Brasilia, Brazil.

Castro, E.R. and E.C. Teixeira. 2012. Rural credit and agricultural supply in Brazil. Agricultural Economics 43(3): 293-302.

Chambers, R.G. 1988. Applied production analysis: a dual approach. Cambridge University Press, Cambridge, UK.

Christoplos, I., P. Sandison and S. Chipeta. 2012. Guide to evaluating rural extension (No. C20-38). Global Forum for Rural Advisory Services - GFRAS, Lausanne, Switzerland.

Christopolos, I. 2010. Mobilizing the potential of rural and agricultural extension. Food and Agriculture Organization of the United Nations, Rome, Italy.

Coelli, T., A. Estache, S. Perelman and L.A. Trujillo. 2003. A primer on efficiency measurement for utilities and transport regulators. The World Bank, Washington, DC, USA.

Coelli, T.J. and G.E. Battese. 1996. Identification of factors which influence the technical inefficiency of Indian farmers. Australian Journal of Agricultural Economics 40(2): 103-128.

Delgado, G.C. 1985. Capital financeiro e agricultura no Brasil, 1965-1985. Editora Icone, São Paulo - SP, Brazil. 
Freitas, C.O., E.C. Teixeira, M.J. Braga and A.M.S. Schuntzemberger. 2019. Technical efficiency and farm size: an analysis based on the Brazilian agriculture and livestock census. Italian Review of Agricultural Economics 74(1): 33-48.

Gasques, J.G., M.R.P. Bacchi and E.T. Bastos. 2017. Impactos do crédito rural sobre variáveis do agronegócio. Revista de Política Agrícola 26(4): 132-140.

Genius, M.G., C.J. Pantzios and V. Tzouvelekas. 2006. Information acquisition and adoption of organic farming practices. Journal of Agricultural and Resource Economics 1: 93-113.

Gonçalves, R.M.L., W.C. Vieira, J.E. Lima and S.T. Gomes. 2008. Analysis of technical efficiency of milkproduction farms in Minas Gerais. Economia Aplicada 12(2): 321-335.

Greene, W.H. 1980. Maximum likelihood estimation of econometric frontier functions. Journal of Econometrics 13(1): 27-56.

Hainmueller, J. 2012. Entropy balancing for causal effects: a multivariate reweighting method to produce balanced samples in observational studies. Political Analysis 1: 25-46.

Heckman, J.J. 1979. Sample selection bias as a specification error. Econometrica 1: 153-161.

Helfand, S.M. and E.S. Levine. 2004. Farm size and the determinants of productive efficiency in the Brazilian Center-West. Agricultural Economics 31(2-3): 241-249.

Helfand, S.M., M.M. Magalhães and N.E. Rada. 2015. Brazil's agricultural total factor productivity growth by farm size. IDB Working paper series 609. Inter-American Development Bank, Washington, DC, USA.

Instituto Brasileiro de Geografia e Estatística (IBGE). 2019. 2006 Agricultural Census microdata. Brazilian Institute of Geography and Statistics - IBGE, Rio de Janeiro, Brazil.

Jondrow, J., C.A.K. Lovell, I.S. Materov and P. Schmidt. 1982. On the estimation of technical inefficiency in the stochastic frontier production function model. Journal of Econometrics 19(2-3): 233-238.

Kageyama, A.A., S.M.P.P. Bergamasco and J.T.A. Oliveira. 2013. Uma tipologia dos estabelecimentos agropecuários do Brasil a partir do censo de 2006. Revista de Economia e Sociologia Rural 51(1): 105-122.

Landau, E.C., R.K. Cruz, A. Hirsch, F.M. Pimenta and D.P. Guimarães. 2012. Variação geográfica do tamanho dos módulos fiscais no Brasil. Embrapa Milho e Sorgo, Sete Lagoas, MG, Brazil.

Lapple, D. and T. Hennessy. 2014. Exploring the role of incentives in agricultural extension programs. Applied Economic Perspectives and Policy 37(3): 403-417.

Lima, A.L.R. 2012. Eficiência produtiva e econômica da atividade leiteira em Minas Gerais. PhD-thesis, Universidade Federal de Lavras, Lavras, Brazil.

Magalhães, M.M., H.M. Souza Filho, M.R. Souza, J.M.F.J. Silveira and A.M. Buainain. 2011. Land reform in NE Brazil: a stochastic frontier production efficiency evaluation. Revista de Economia e Sociologia Rural 49(1): 9-30.

Mariano, M.J., R. Villano and E. Fleming. 2010. Are irrigated farming ecosystems more productive than rainfed farming systems in rice production in the Phillippines? Agriculture, Ecosystems and Environment 139(4): 603-610.

Mendes, S.M., E.C. Teixeira and M.A. Salvato. 2009. Investimentos em infra-estrutura e produtividade total dos fatores na agricultura brasileira: 1985-2004. Revista Brasileira de Economia 63(2): 91-102.

Moura, A.C.F., A.S. Khan and L.M.R. Silva. 2000. Extensão rural, produção agrícola e benefícios sociais no Estado do Ceará. Revista Econômica do Nordeste 2: 212-234.

Neves, M., C. Freitas, F. Silva, D. Costa and M. Braga. 2020. Does access to rural credit help decrease income inequality in Brazil? Journal of Agricultural and Applied Economics 52(3): 440-460.

Nunes, E.M., S. Schneider, J. Matos Filho, K.F.G. Nunes and J.R. de Aquino. 2014. Políticas Agrárias e Agrícolas no Contexto do Desenvolvimento do Nordeste: evolução, desafios e perspectivas. Planejamento e Políticas Públicas 43: 91-126.

Peixoto, M. 2014. Mudanças e desafios da extensão rural no Brasil. In: A.M. Buainain, E. Alves, J.M. Silveira, Z. da Navarro (eds.) O mundo rural no Brasil do século 21. Empresa Brasileira de Pesquisa Agropecuária, Brasília, Brazil, pp. 891-924.

Pettan, K.B. 2010. A Politica Nacional de Assistência Técnica e Extensão Rural PNATER: percepções e tendências. PhD-thesis, Universidade Estadual de Campinas, Campinas, SP, Brazil. 
Plata, L.E.A. and R.L. Fernandes. 2012. A nova Assistência Técnica e Extensão Rural Brasileira. Revista Perspectiva em Gestão, Educação e Tecnologia 1(1): 1-12.

Rada, N. and C. Valdes. 2012. Policy, technology, and efficiency of Brazilian agriculture. Report 137. United States Department of Agriculture, Economic Research Service, Washington, DC, USA.

Rivera, W. and G. Alex. 2004. Privatization of extension systems: case studies of international initiatives. The World Bank, Washington, DC, USA.

Rodrigues, C.M. 1997. Conceito de seletividade de políticas públicas e sua aplicação no contexto da política de extensão rural no Brasil. Cadernos de Ciência \& Tecnologia 14(1): 113-154.

Schuntzemberger, A.M. and A.V. Sampaio. 2018. Eficiência técnica dos estabelecimentos rurais Brasileiros: o que nos dizem os microdados do censo agropecuário 2006? Boletim De Indústria Animal 75: 1-11.

Swinnen, J.F. and M. Mertens. 2007. Globalization, privatization, and vertical coordination in food value chains in developing and transition countries. Agricultural Economics 37: 89-102.

Teixeira, E.C., M.H. Miranda and C.O. Freitas. 2014. Políticas governamentais aplicadas ao agronegócio. Editora UFV, Viçosa, MG, Brazil.

Theriault V. and R. Serra. 2014. Institutional environment and technical efficiency: a stochastic frontier analysis of cotton producers in West Africa. Journal of Agricultural Economics 65(2): 383-405. 